\title{
CARACTERÍSTICAS ESTRUTURAIS E MORFOGÊNESE DE AZEVÉM ANUAL EM RESPOSTA AO NITROGÊNIO
}

\author{
Sebastião Brasil Campos Lustosa \\ Orientador: Prof. Dr. Aníbal de Moraes
}

\section{RESUMO}

A morfogênese foliar do azevém, ou seja, a sua dinâmica do aparecimento, elongação e senescência foliar e, o ajuste de um modelo de diluição de nitrogênio, foram avaliados sob cinco doses de nitrogênio $(0,75,150,225$ e $300 \mathrm{~kg} \mathrm{~N}$.ha-1), no período de maio a outubro de 1998. Para se avaliar os parâmetros morfogênicos e estruturais do azevém, utilizaram-se vinte perfilhos marcados por unidade experimental, num delineamento inteiramente casualizado com três repetições. Para o ajuste do modelo de diluição, foram cortadas semanalmente parcelas rentes ao solo. O nitrogênio promoveu aumentos mais pronunciados nas taxas de aparecimento e elongação durante o período de estabelecimento, o que resultou na redução do filocrono. A taxa de senescência foliar foi principalmente afetada pela redução na disponibilidade de nitrogênio. O índice de área foliar foi a variável que melhor caracterizou os efeitos da adubação nitrogenada e o modelo de diluição. O nível $225 \mathrm{Kg} \mathrm{N}$.ha-1 não limitou o desenvolvimento do azevém. Considerando que não houve limitações hídricas e nutricionais, então o nitrogênio aplicado condicionou o desenvolvimento aéreo e o acúmulo de forragem do azevém anual.

\begin{abstract}
The leaf morfogenesis of the Italian ryegrass, in other words, its leaf appearance dynamics, elongation and senescence and, the adjustment of a nitrogen dilution model, were evaluated under five levels of nitrogen $(\mathrm{O}, 75,150,225$ and $300 \mathrm{~kg} \mathrm{~N}$.ha-1), during May to October of 1998. To evaluate morfogenetic parameters, twenty marked tillers were used by experimental unit, in a completely randomized design with three replicates. For the adjustment of the dilution model, cuts were done weekly nearby portions to the soil. Nitrogen promoted more pronounced increases in leaf appearance and elongation rates during the establishment period, which resulted in the reduction of the phyllochron. The leaf senescence rate was affected mainly by the reduction in the readiness of nitrogen. The leaf area index was the variable that best characterized the effects of the applied nitrogen. The tratament $225 \mathrm{~kg} \mathrm{~N}^{-}$ha $^{-1} \mathrm{didn}^{\prime} \mathrm{t}$ limit the development of the italian ryegrass. Considering there were no hydric and nutritional limitations, then the applied nitrogen conditioned the aerial development and the forage accumulation of the italian ryegrass.

Key-words: leaf appearance rate, phyllochron, Lolium multíflorum, nitrogen.
\end{abstract}

